\title{
Growing Site Characteristics of Agathis labillardieri Warb in the Natural Forests of Siwi Momiwaren, West Papua
}

\author{
By: \\ Rima Herlina Setiawati Siburian*, Mei Trirbo, Rusdi Angrianto \\ Faculty of Forestry, Universitas Papua. Jl. Gunung Salju, Amban, Manokwari, 98314, West Papua, Indonesia \\ *E-mail: r.siburian@unipa.ac.id
}

\begin{abstract}
Agathis labillardieri Warb is one of the copal-producing tree species that only distributed in Papua. In connection with regional development, the existence of this species has been a significant concern. Therefore, it is necessary to study the characteristics of A. labillardieri Warb in their natural growing areas in the natural protected forest of Siwi Momiwaren. The data were collected by using the line plot method systematic sampling method with nesting plot. The data were then analyzed to determine the species relative density, frequency, dominance, important value index (IVI), and growth characteristics. The results showed that A. labillardieri Warb had the highest IVI at all levels of growth, with the highest diversity index at the seedling level of 3,49. When viewed from the relationship of the presence of species with the characteristics of the growing site, the content of Mg and Na significantly affected the presence of this species in the natural forest area of South Manokwari Siwi Momiwaren.
\end{abstract}

Keywords: Agathis labillardieri Warb, growing site characteristics, Siwi Momiwaren, West Papua

\section{INTRODUCTION}

Agathis is a genus of the Araucariaceae family. Trees of this genus are characterized by large trunks and few branches, while in a young tree, the canopy of this type of tree generally irregular (Darma et al. 2019; Ebi 2015; Wahyudi et al. 2014). In Indonesia, Agathis species is widely distributed, covering the islands of Sumatra, Kalimantan, Sulawesi, Maluku, and Papua. Even some types of them spread naturally in specific areas such as Agathis alba Warb. (Sumatra, Maluku), Agathis borneensis Warb. (Kalimantan), Agathis hauri (Sulawesi), Agathis philippines (Sulawesi), and Agathis labillardieri Warb. (Papua) (Martawijaya et al. 2005).

Farjon (2013) states that Agathis labillardieri Warb is one of the conifer species of the Araucariaceae family and distributes naturally in Papua, Queensland-Australia, and Papua New Guinea. The species has been included in the category of near threatened (NT) based on data from the International Union for Conservation of Nature (Farjon 2013). This tree species is one of the producers of copal and widely used as an industrial material for paints, varnishes, methylates, red shells, burn varnishes, linoleum, inks, textile coatings, waterproofing and drying liquids. Resmeiliana et al. (2014) stated that copal from A. labillardieri Warb contains pinene, linonen, and dipentene of $97,4 \%$, sesquiterpene oxide of $0,5 \%$, and resin content of $0,7 \%$. Khalil et al. (2015) added that adding nutrients to the soil would improve the quality and quantity of plant resin. When it is viewed from its solubility, copal is a material that can dissolve in glacial acetic acid, which is an excellent adhesive (Ando and Wiyono 1988).

Management of the genetic resources of $A$. labillardieri Warb in the tropical natural forests of Papua has yet to be managed and utilized optimally due to the absence of accurate data on this species, such as its potential, distribution, and characteristics of the growing site. 
Although the benefits of these plants in terms of copal sap produced is an economic opportunity for the management of non-timber forest products, the research on the characteristics of the location of this tree plant is essential information for the future development of $A$. labillardieri Warb species. Siwi Momiwaren is one of the natural forest areas where A. labillardieri Warb grows in South Manokwari. However, following equitable development throughout Indonesia and regional development, there have been some areas of the forest began to be cleared for allotment of road construction, buildings, and other uses. In this context, research on the characteristics of $A$. labillardieri Warb is fundamental to avoid extinction from its natural habitat.

\section{MATERIALS AND METHODS}

\section{The Study area}

Research on the characteristics of $A$. labillardieri Warb growth sites was conducted in the Siwi natural forest area, Momiwaren District, South Manokwari Regency (13359'8,1276" -

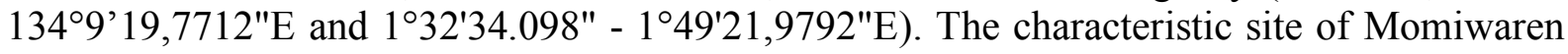
protected forest is lowland forest, with mild to severe topography (Figure 1). The soil analysis was carried out in the soil laboratory of Gadjah Mada University, Yogjakarta.
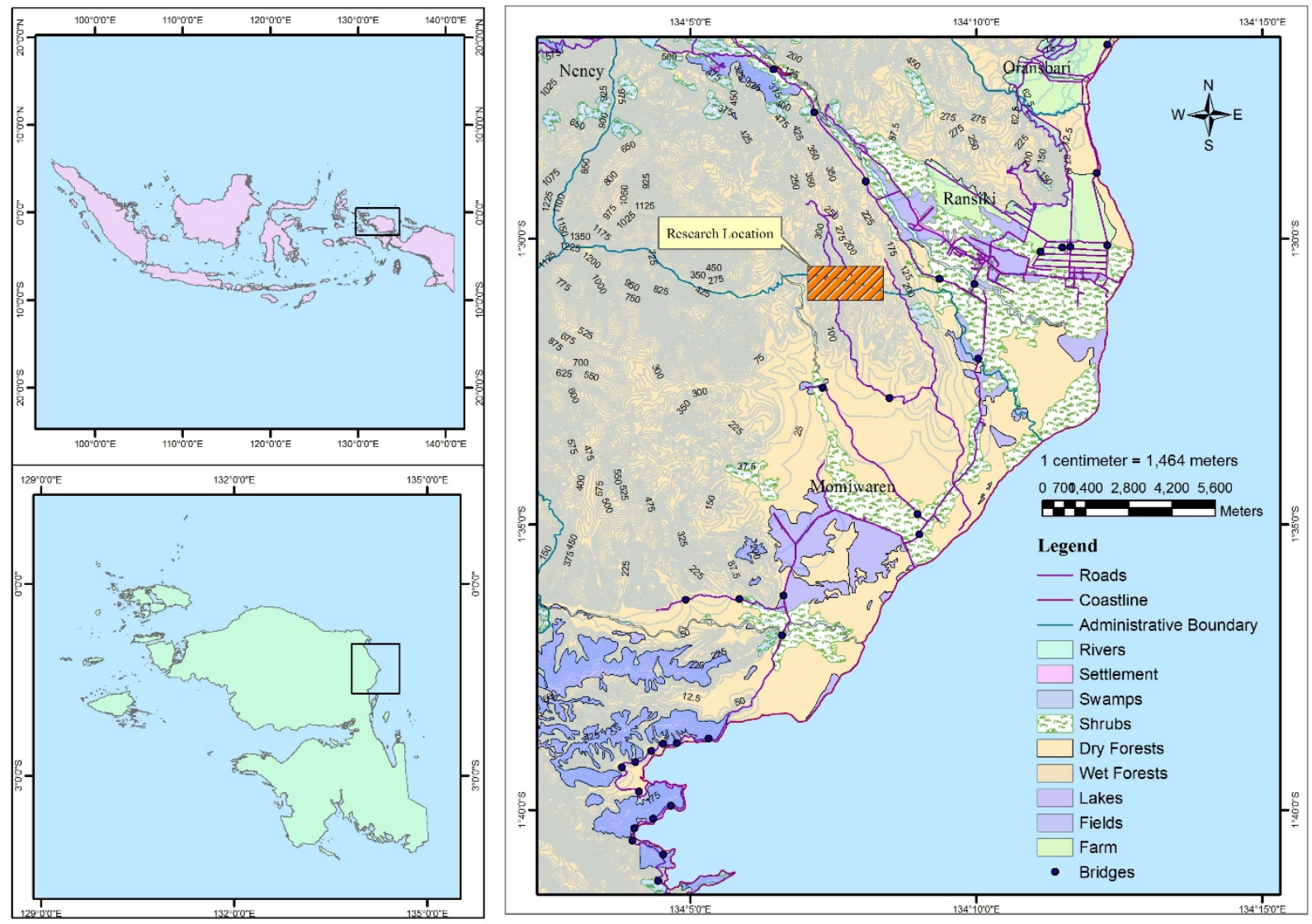

Figure 1. A. labillardieri Warb research location map in Siwi natural forest area, Momiwaren District, South Manokwari Regency.

The tools used in this study include 1: 10.000 scale work maps, stationery, machetes, cuttings, tally sheets, roll meters, nylon ropes, trash bags, pocket meters, measuring tape, sample plastics, etiquette hanging, altimeter, compass, Haga meter, lux meter, GPS, Helling meter, clinometer, thermohydrometer, and other supporting equipment. The materials used in 
this study were newsprint (compass), 70\% alcohol, soil samples, and red paint as markers of paths and trees.

\section{Data Collection}

\section{Plant Samples}

This research was conducted using the sampling line-plot inventory method with a sampling intensity of $15 \%$ to observe A. labillardieri Warb specifically. The observation formed seven lines, where the line length was 500 meters. The distance between the plots was 100 meters, and the distance between the lines was 100 meters. Therefore, 35 observation plots were obtained. The selection of observation path was carried out using the Systematic Sampling with Random Start system in which the first path was determined randomly, and the next path was determined by line plot sampling (Kershaw et al. 2016; Saputra et al. 2016; Tiurmasari et al. 2016). The observation at the stage of growth was measured as follows: $20 \mathrm{~m} \times 20 \mathrm{~m}$ for trees, $10 \mathrm{~m} \times 10 \mathrm{~m}$ for poles, $5 \mathrm{~m} \times 5 \mathrm{~m}$ for saplings, and $2 \mathrm{~m} \times 2 \mathrm{~m}$ for seedlings. Each plant encountered throughout the plot was measured at diameter at breast height (dbh) using a ribbon diameter, then classified whether it included trees, poles, or saplings. This dbh size was used as a basis for calculating the basal area for the tree and pole phases. Specimens with stem diameters of less than $10 \mathrm{~cm}$ (seedlings and saplings) were only counted the number of individuals of each species from each sub-plot. Some plant species were identified directly on the plot, while for others that could not be identified, the herbarium specimens were prepared. The herbarium specimen was then identified by referring to the voucher specimen held by the Manokwariense Herbarium.

\section{The growing site characteristics samples}

Observations were conducted on a circle of $17,8 \mathrm{~m}$ for observation of growing sites. The data for growth characteristics observed were soil chemical properties including $\mathrm{pH}$, organic matter content of nitrogen $(\mathrm{N})$, phosphorus $(\mathrm{P})$, potassium $(\mathrm{K})$ available, Calcium $(\mathrm{Ca})$, Sodium $(\mathrm{Na})$, Magnesium $(\mathrm{Mg})$ and capacity cation exchange (CEC). Soil samples were taken randomly in each subplot of $20 \mathrm{~m} \times 20 \mathrm{~m}$ at a depth of $0-20 \mathrm{~cm}$ and $>20 \mathrm{~cm}$. Soil samples from $20 \mathrm{~m} \mathrm{x}$ $20 \mathrm{~cm}$ subplots were then mixed into one to get soil samples from $20 \mathrm{~cm} \times 100 \mathrm{~cm}$ plots.

\section{Data analysis}

Data were analyzed to obtain the Important Value Index by using Microsoft Excel 2010 and QGIS 2.14.1-Essen for windows. Relative Density (RD), Relative Frequency (RF), Relative Dominance (RD.), and Importance Value Index (IVI) were calculated and analyzed according to the formula of Hakkenberg et al. (2016). The IVI was performed only for tree level and was calculated to figure out the distribution of each tree species in terms of dominance (Trogisch et al. 2017).

$$
\begin{gathered}
\text { Relative density }(\%)=\frac{\text { No. of individuals of a species }}{\text { Total number of individuals in the sample }} \times 100 \% \\
\text { Relative dominance }(\%)=\frac{\text { Basal area of a species }}{\text { Total basal area in the sample }} \times 100 \% \\
\text { Relative frequency }(\%)=\frac{\text { Sampling units containing a species }}{\text { Sum of all frequency }} \times 100 \%
\end{gathered}
$$

The basal area was only performed for trees. The basal area (BA) was calculated by considering the diameter for the tree species. Species i, 0,7854 was phi divided by 4 . Then, BA 
per hectare where BA of tree species was divided by the area of plots $\left(\mathrm{m}^{2}\right.$ ha-1) as density. The BA for each tree species was to describe how large the tree species dominated a location.

The diversity index was calculated as $\mathrm{H}^{\prime}=-\Sigma$ pi $\ln (\mathrm{pi}$ ), the Shannon-Weiner diversity index (Erwin et al. 2017; Omayio and Mzungu 2019). The index was calculated for each of the four growth stages (seedling, sapling, pole, and tree). Diversity criteria were following Hakkenberg et al. (2016), the vegetation has a high level of diversity if the diversity index $\mathrm{H}^{\prime}>$ 3. While it was categorized as moderate if the value of $\mathrm{H}^{\prime}$ is between 1 and 3 , and it is categorized low if the value of $\mathrm{H}^{\prime}<1$. The Shannon-Weiner diversity index was singled out as parameters to describe the distribution of each species in terms of the number of individuals by computing evenness (E) (Anandan et al. 2014; Laksemi et al. 2019; Siahaan et al. 2019).

Evenness was measured using $\mathrm{E}$ as the number of species. Frequency $=$ All species of plant life-forms were described using frequency. Furthermore, the number of plots where the species tree was present was divided by the total number of sample plots. Hence, the frequency was calculated as where Fri was the frequency of species i, $n$ was the number of plots in which species $\mathrm{i}$ was found, $\mathrm{N}$ was the total number of sample plots.

Dominance in a community and plant regeneration stages were analyzed using the Dominance Index (Ds) (Turkis and Elmas 2018). Ds $=(\mathrm{ni} / \mathrm{N})^{2}$. Where Ds is the domination index, $\mathrm{ni}$ is the importance value of the species, and $\mathrm{N}$ is the total importance. On the basis of ecological dominance (Ds) in a community, the species were grouped into three categories;(Bechtold 2003) (i) $0,00<\mathrm{Ds}<0,30=$ low dominance, (ii) $0,30<\mathrm{Ds}<0,60=$ intermediate dominance, and (iii) $0,60<$ Ds $<1,00=$ high dominance.

Furthermore, to find out whether the characteristics of the place of growth affect the growth of $A$. labillardieri Warb, then testing was conducted using multiple linear regression models. The general equations used were as follows (Rosalia 2008):

$$
\begin{aligned}
& \mathrm{Y}=\mathrm{a}+\mathrm{b} 1 \mathrm{x} 1+\mathrm{b} 2 \times 2+\mathrm{b} 3 \times 3+\mathrm{b} 4 \times 4 \\
& \text { Where: } \\
& \mathrm{Y}=\text { Area of base plane } \text { A. labillardieri Warb per plot } \\
& \mathrm{a}=\text { constant } \\
& \mathrm{b}=\text { Regression coefficient } \\
& \mathrm{x} 1=\mathrm{pH} \\
& \mathrm{x} 2=\text { Nitrogen } \\
& \mathrm{x} 3=\text { Phosphorus } \\
& \mathrm{x} 4=\text { Potassium } \\
& \mathrm{x} 5=\text { Calcium } \\
& \mathrm{x} 6=\text { Sodium } \\
& \mathrm{x} 7=\text { Magnesium } \\
& \mathrm{x} 8=\text { Cation exchange capacity }
\end{aligned}
$$

\section{RESULTS AND DISCUSSION}

\section{Potential of $A$. labillardieri Warb}

The results of an inventory of tree vegetation from 35 observation plots conducted in the natural forest of Kampung Siwi, Momiwaren District, South Manokwari Regency, found 64 species of tree vegetation consisting of 49 species of tree phase, 28 species of pole phase, 47 species of sapling phase, and 54 species of seedling. These results indicated that the number of species obtained at the seedling phase was higher than in other phases. The results showed that the natural regeneration process in this location has been going well. 
A. labillardieri Warb was found at this location has high IVI values at all plant growth rates (Table 1). The IVI that was supported by high individual relative density values indicated that the species could adapt well in this location. This area was included in the area of tropical rain forests with varying topography levels and diverse soil (Kartikasari et al. 2012).

Table 1. Four species with the highest IVI at each growth phase.

\begin{tabular}{|c|c|c|c|c|c|}
\hline Family & Species & $\begin{array}{c}\text { Relative } \\
\text { density } \\
(\%)\end{array}$ & $\begin{array}{c}\text { Relative } \\
\text { frequency } \\
(\%)\end{array}$ & $\begin{array}{c}\begin{array}{c}\text { Relative } \\
\text { dominance } \\
(\%)\end{array} \\
\end{array}$ & IVI \\
\hline \multicolumn{6}{|l|}{ Seedling } \\
\hline Araucariaceae & Agathis labillardieri warb & 12,15 & 10,38 & - & 22,53 \\
\hline Winteraceae & Drymis sp. & 5,58 & 4,86 & - & 10,45 \\
\hline Araucariaceae & Araucaria cunninghamii & 4,27 & 5,08 & - & 9,35 \\
\hline $\begin{array}{l}\text { Meliaceae } \\
\text { Sapling }\end{array}$ & Aglaia sp. & 4,73 & 4,54 & - & 9,27 \\
\hline Araucariaceae & Agathis labillardieri warb & 14,18 & 11,57 & - & 25,76 \\
\hline Araucariaceae & Araucaria cunninghamii & 6,15 & 7,29 & - & 13,44 \\
\hline Prunaceae & Prunus sp. & 6,63 & 6,75 & - & 13,39 \\
\hline $\begin{array}{l}\text { Podocarpaceae } \\
\text { Pole }\end{array}$ & Podocarpus sp. & 7,05 & 4,39 & - & 11,45 \\
\hline Araucariaceae & Agathis labillardieri warb & 21,76 & 5,56 & 2,31 & 29,63 \\
\hline Prunaceae & Prunus sp. & 21,06 & 6,03 & 1,95 & 29,05 \\
\hline Myrtle & Syzygium sp. & 12,26 & 6,03 & 1,37 & 19,67 \\
\hline $\begin{array}{l}\text { Meliaceae } \\
\text { Tree }\end{array}$ & Aglaia sp. & 11,45 & 6,03 & 1,30 & 18,80 \\
\hline Araucariaceae & Agathis labillardieri warb & 17,86 & 14,49 & 4,02 & 36,39 \\
\hline Prunaceae & Prunus sp. & 15,29 & 13,01 & 5,19 & 33,49 \\
\hline Myrtle & Syzygium $s p$ & 9,45 & 10,41 & 1,57 & 21,44 \\
\hline Araucariaceae & Araucaria cunninghamii & 7,21 & 6,93 & 5,33 & 19,486 \\
\hline
\end{tabular}

The IVI value is an indicator used to determine the effect of changes in the number of species in an area. The IVI value of $A$. labillardieri Warb at each phase showed a higher value compared to other types in the region. However, the results in this study were still low when compared with the results of the study by Adalina and Sewitri (2020), which stated that the IVI value obtained from the Agathis dammara research results in Mount of Halimun Salak National Park was $300 \%$.

In the stable forest area, it is generally found that the level of growth of tree species would evenly distribute in all regions. However, sometimes the number of individuals at a particular growth stage decreases, which may have an impact on population decline at certain times. Conversely, if the number of tillers is at a large number, the population may stable and may even experience an increase (Kaiser et al. 2019). To find out the stability of Siwi Momiwaren's natural forest area, a calculation was carried out to determine the diversity value and species richness (Table 2).

Indriyanto (2012) stated that the smaller the value of the dominance index (C), the dominance pattern of the species would increasingly distribute and thus spread evenly in the area. It would be seen that the dominance index obtained from the results of calculations in the Siwi Momiwaren natural forest area ranged from 0,043 to 0,086 . This showed that the species found in this forest area did not experience a concentration of one species either at seedling, sapling, pole, and tree phases, instead several species dominate the region altogether. The nearly zero values correspond to low diversity or a more homogeneous plant ecosystem (Karyati et al. 2013). 
Table 2. The number of species and index of diversity for each growth stage.

\begin{tabular}{lccccc}
\hline $\begin{array}{l}\text { Growth } \\
\text { Stage }\end{array}$ & $\begin{array}{c}\text { Number of } \\
\text { species }\end{array}$ & $\begin{array}{c}\text { Number of } \\
\text { individuals }\end{array}$ & $\begin{array}{c}\text { Dominance } \\
\text { index (C) }\end{array}$ & $\begin{array}{c}\text { Evenness } \\
\text { value }\end{array}$ & $\begin{array}{c}\text { Diversity } \\
\text { index } \\
\text { (H') }\end{array}$ \\
\hline Seedling & 54 & 544 & 0,043 & 0,877 & 3,499 \\
Sapling & 47 & 327 & 0,054 & 0,852 & 3,279 \\
Poles & 28 & 247 & 0,133 & 0,708 & 2,358 \\
Tree & 49 & 208 & 0,086 & 0,742 & 2,886 \\
\hline
\end{tabular}

This can also be seen in the calculation of the evenness index value where the community found was quite balance. At the seedling phase, the highest evenness index value was 0,877 , Cáceres et al. (2013) states that the value of evenness that is close to one shows that the community relation in an area is more evenly distributed, and if the value is close to zero then the community relation is increasingly uneven. Evenness index is an indicator that would be used to assess the indication of dominance in each species in a community.

The species diversity index $\left(\mathrm{H}^{\prime}\right)$ (Table 2 ) showed that it has a high $\mathrm{H}^{\prime}$ of 3,499 at the seedling phase. The calculated value of $\mathrm{H}^{\prime}$ shown at the seedling and sapling phases indicated that each species present of the stand has the same abundance. According to Pamoengkas et al. (2018), species diversity could also be used to express community structure and measure community stability. Siburian et al. (2017) stated that the value of species diversity would tend to be high in older plant communities. In contrast, for communities that are categorized as newly formed, the value of diversity is generally low. The stability of a habitat greatly influences the level of species diversity, which is determined by the number of species and the number of individuals of each species found in the area. The results of the study by (Pamoengkas et al. 2019) in the production forest on logged-over forest areas in Central Kalimantan, showed the average index at all phases has values $>3$. Similarly the results of Sofiah et al. (2018) in the Besiq Bermai East Kalimantan forest, the forest area was a primary forest that was started undergoing degradation and becoming a secondary forest, which shows a value of $\mathrm{H}>3$.

\section{Characteristics of growing sites A. labillardieri Warb}

Soil is one of the characteristics of the growing site that plays a role in supporting the growth and production of plants. In addition to functioning as plants growing sites, soil also plays a role in holding and providing water nutrients needed by plants to support plant growth (Jiang et al. 2015). In its formation, various factors influence growth, such as climate, parent material, topography, organisms, and time.

Agathis plants generally grow in primary forests with sandy, rocky, or clay soil conditions that are not permanently inundated (Frezza et al. 2020). While Escapa et al. (2018) stated that the distribution of A. labillardieri Warb in Papua started from peat forest to the low mountain forest. In addition, this species is also found on Biak and Yapen Islands, which containing ultrafamic soils and limestone. Andriani (2016) states that A. labillardieri Warb generally grows on calcareous and alluvial soils with rocky and rocky soil conditions with shallow solum $( \pm 10 \mathrm{~cm})$ on rocky, medium $( \pm 15 \mathrm{~cm})$ soils and rocky soils $(\geq 20 \mathrm{~cm})$. The results of this study indicated several things that are different from some previous studies, especially in the characteristics of the soil (Table 3 ).

The availability of nutrients in the soil is strongly influenced by soil $\mathrm{pH}$ and CEC. Hardjowigeno (2003) states that the chemical nature of the soil is very closely related to soil fertility, which is primarily influenced by excellent CEC values. If the value of the CEC is low, the soil will not be able to absorb and provide adequate nutrients for plant growth. 
Table 3. Average soil characteristics.

\begin{tabular}{cccccccccc}
\hline Path & $\begin{array}{c}\text { Basal area } \\
\text { A. labillardieri Warb }\end{array}$ & $\mathbf{p H}$ & $\mathbf{N}$ & $\mathbf{P}$ & $\mathbf{K}$ & $\mathbf{C a}$ & $\mathbf{N a}$ & $\mathbf{M g}$ & $\mathbf{C E C}$ \\
\hline 1 & 1,10 & 4,90 & 0,44 & 7,44 & 1,07 & 3,68 & 0,85 & 0,84 & 45,34 \\
2 & 1,05 & 5,33 & 0,42 & 7,43 & 1,14 & 3,65 & 0,84 & 0,82 & 45,34 \\
3 & 0,66 & 5,14 & 0,41 & 7,41 & 1,16 & 3,66 & 0,85 & 0,84 & 45,35 \\
4 & 0,81 & 5,48 & 0,44 & 7,44 & 1,07 & 3,66 & 0,86 & 0,85 & 45,33 \\
5 & 0,51 & 4,48 & 0,43 & 7,44 & 1,12 & 2,94 & 0,86 & 0,83 & 45,30 \\
6 & 0,55 & 5,29 & 0,44 & 7,48 & 1,05 & 3,04 & 0,86 & 0,79 & 45,33 \\
7 & 0,20 & 5,07 & 0,42 & 7,44 & 1,06 & 2,62 & 0,84 & 0,70 & 45,34 \\
\hline
\end{tabular}

The results of tests conducted on the characteristics of the soil in the seven paths indicated that the average chemical value of the soil tested influenced the presence of $A$. labillardieri Warb by using multiple linear regression analysis. The independent variables measured were the basal area. In contrast, the independent variables measured were $\mathrm{pH}$, Nitrogen $(\mathrm{N})$, Phosphorus (P), Potassium (K), Calcium (Ca), Sodium (Na), Magnesium (Mg) and exchange capacity cation (CEC). Calculations were made on the plot of the finding of A. labillardieri Warb (LBDS) and all non A. labillardieri Warb plots in the research path. Based on the results of multiple linear analyzes, the regression equation values obtained as in the following equation: $\mathrm{Y}=-210,5+133 \mathrm{x} 1-2,89 \mathrm{x} 2+7,18 \mathrm{x} 3-0,79 \mathrm{x} 4+14,95 \times 5+6,14 \mathrm{x} 6-15,18 \times 7+2,47 \mathrm{x} 8$. The diversity analysis of the multiple linear equation models is shown in Table 4.

Table 4. Analysis of multiple linear regression of A. labillardieri Warb on soil factors.

\begin{tabular}{lccccc}
\hline Model & Sum of square & df & $\begin{array}{c}\text { Mean } \\
\text { square }\end{array}$ & F & Sig \\
\hline Regression & 1,327 & 8 & 0,166 & 1,917 & $0,123 \mathrm{a}$ \\
Residual & 1,471 & 17 & 0,087 & & \\
$\quad$ Total & 2,798 & 25 & & & \\
\hline
\end{tabular}

The results of this regression analysis show that the variables $x 1$ to $x 8$ affect the value of Y. However, when it was viewed in more detail, there appears to be multicollinearity between the independent variables so that multiple regression was performed through stepwise, and the following equation is obtained: $Y=-41,01+11,442 \times 5-0,317 \times 7$. The results of the diversity analysis of the multiple linear equation models are presented in Table 5.

Table 5. The results of the diversity analysis of the multiple linear equation models.

\begin{tabular}{lccccc}
\hline \multicolumn{1}{c}{ Model } & Sum of square & df & Mean square & F & Sig \\
\hline Regression & 0,567 & 1 & 0,567 & 6,096 & $0,21 \mathrm{a}$ \\
Residual & 2,231 & 24 & 0,093 & & \\
Total & 2,798 & 25 & & & \\
\hline
\end{tabular}

The results indicated that the Siwi Momiwaren natural forest area has soil quality with $\mathrm{Ca}$ and $\mathrm{Mg}$ levels, which is very influential for the growth of A. labillardieri Warb. The elements $\mathrm{Ca}$ and $\mathrm{Mg}$ are essential elements for plants. Lack of these two elements would cause stunted plant growth and also have a negative impact on the production process. Also, these two elements would affect the value of CEC and saturation of the base (KB) of land in an area. The calcium content in this region ranged from 2,62 - 3,68 meg/100 g. Medium Magnesium $(\mathrm{Mg})$ content ranged from 0,7 to $0,86 \mathrm{meg} / 100 \mathrm{~g}$. 
Wasis et al. (2018) stated that the application of potassium fertilizer $(\mathrm{KCl})$ twice in 6 months shows a very significant increase in the production of Agathis spp (copal) sap. In this study, it was observed that the condition of the plant was quite good, with a substantial production of latex (Figure 2). It was estimated that the characteristics of $A$. labillardieri Warb growing sites in this region were very supportive of the growth and production of sap (copal). Therefore, the development of the growing site characteristics of A. labillardieri Warb needed to be taken into consideration for future copal production.

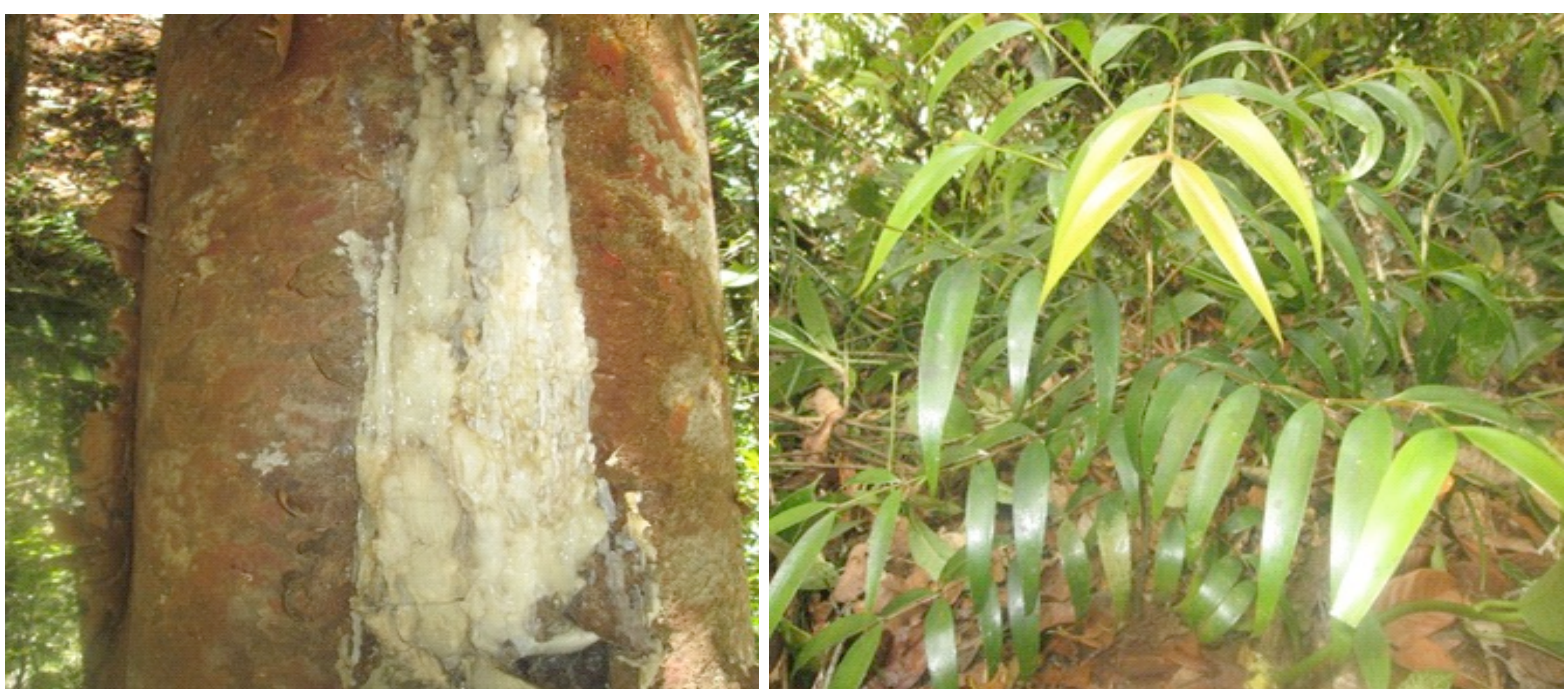

Figure 2. A. labillardieri Warb stem and saplings.

\section{CONCLUSIONS}

The IVI value of $A$. labillardieri Warb at each phase shows a higher value compared to other types in the region. The results showed no domination of one species either at seedling, sapling, pole and tree phases; instead, several species dominate the region altogether. The Siwi Momiwaren natural forest area has soil quality with $\mathrm{Ca}$ and $\mathrm{Mg}$ levels that are very influential for the growth of $A$. labillardieri Warb.

\section{ACKNOWLEDGMENTS}

The author would like to thank the Momiwaren district government for allowing in conducting research on the Siwi momiwaren natural forest area, and the head of the forestry research center who assisted in the field. We would also like to give our thanks to the integrated laboratory of the University of Papua (UNIPA), as well as the Research and Community Services of the University of Papua, for contributing to this study.

\section{REFERENCES}

Adalina, Y., and Sewitri, R. 2020. Vegetation Analysis, Physico-Chemical Properties and Economic Potential of Damar (Agathis dammara) in Mount Halimun Salak National Park, West Java, Indonesia. Biodiversitas Journal of Biological Diversity 21(3): 1122-1129. DOI: 10.13057/biodiv/d210336

Anandan, G., Thomas, A., Benickson, C., Chitra, D. R., Geethu, M., Augustine, J., Mithun, R. 
M., Shiva, R., and Kavipriya, J. 2014. Estimation of Tree Species Diversity in Four Campuses of Roever Institutions using Simpsons Diversity Index. Journal of Biodiversity \& Endangered Species 2(4): 1-3. DOI: 10.4172/2332-2543.1000135

Ando, Y., and Wiyono, B. 1988. Sifat-sifat Kopal Manila dari Pekalongan Timur dan Banyumas Barat. Jurnal Penelitian Hasil Hutan 5(6): 353-356.

Andriani, R. 2016. Pertumbuhan Semai Damar (Agathis dammara Lamb) pada Media Tailing dengan Penambahan Pupuk Kompos Dana Arang Tempurung Kelapa. Institut Pertanian Bogor, Bogor.

Bechtold, W. A. 2003. Crown Position and Light Exposure Classification - An Alternative to Field-Assigned Crown Class. Northern Journal of Applied Forestry 20(4): 154-160. DOI: 10.1093/njaf/20.4.154

Cáceres, M. De, Legendre, P., and He, F. 2013. Dissimilarity Measurements and the Size Structure of Ecological Communities. Methods in Ecology and Evolution 4(12): 11671177. DOI: $10.1111 / 2041-210 X .12116$

Darma, H. A., Bintoro, A., and . D. 2019. Faktor-Faktor Penentu Perubahan Kondisi Keanekaragaman Flora dan Fauna di Sub-Sub DAS Khilau, Sub DAS Bulog, DAS Sekampung. Jurnal Sylva Lestari 7(2): 204-213. DOI: 10.23960/js127204-213

Ebi. 2015. Keragaman Genetik Jenis Agathis Sp Berbagai Provenansi Berdasarkan Penanda Mikrosatelit Simple Squense Repeat. Universitas Hasanuddin, Makassar, Indonesia.

Erwin, Bintoro, A., and Rusita. 2017. Keragaman Vegetasi di Blok Pemanfaatan Hutan Pendidikan Konservasi Terpadu (HPKT) TAHURA Wan Abdul Rachman, Provinsi Lampung. Jurnal Sylva Lestari 5(3): 1-11. DOI: 10.23960/js1351-11

Escapa, I. H., Iglesias, A., Wilf, P., Catalano, S. A., Caraballo-Ortiz, M. A., and Cúneo, N. R. 2018. Agathis Trees of Patagonia's Cretaceous-Paleogene Death Landscapes and Their Evolutionary Significance. American Journal of Botany 105(8): 1345-1368. DOI: 10.1002/ajb2.1127

Farjon, A. 2013. Agathis labillardieri. The IUCN Red List of Threatened Species $<$ https://www.iucnredlist.org/species/42193/2960026> (Aug. 25, 2020).

Frezza, C., Venditti, A., Vita, D. De, Toniolo, C., Franceschin, M., Ventrone, A., Tomassini, L., Foddai, S., Guiso, M., Nicoletti, M., Bianco, A., and Serafini, M. 2020. Phytochemistry, Chemotaxonomy, and Biological Activities of the Araucariaceae Family — a Review. Plants. DOI: 10.3390/plants9070888

Hakkenberg, C. R., Song, C., Peet, R. K., and White, P. S. 2016. Forest Structure as a Predictor of Tree Species Diversity in the North Carolina Piedmont. Journal of Vegetation Science 26(7): 1151-1163. DOI: $10.1111 /$ jvs. 12451

Hardjowigeno, S. 2003. Ilmu Tanah. Akademika Pressindo, Kota Padang.

Indriyanto. 2012. Ekologi Hutan. Bumi Aksara, Jakarta, Indonesia.

Jiang, Y., Zang, R., Lu, X., Huang, Y., Ding, Y., Liu, W., Long, W., Zhang, J., and Zhang, Z. 2015. Effects of Soil and Microclimatic Conditions on the Community-Level Plant Functional Traits Across Different Tropical Forest Types. Plant and Soil 390(1-2): 351367. DOI: $10.1007 / \mathrm{s} 11104-015-2411-y$

Kaiser, C. M., O’Shea, M., and Kaiser, H. 2019. A New Species of Indo-Papuan Groundsnake, Genus Stegonotus Duméril et al., 1854 (Serpentes, Colubridae), From the Bird's Head Peninsula of West Papua, Indonesia, With Comments on Differentiating Morphological Characters. Zootaxa 4590(2): 201-230. DOI: 10.11646/zootaxa.4590.2.1

Kartikasari, S. N., Marshall, A. J., and Beehler, B. 2012. Ekologi Papua. Yayasan Pustaka Obor Indonesia Periplus Editions (HK) Ltd. and Conservation International, Yogyakarta, Indonesia.

Karyati, Ipor, I. B., Jusoh, I., Wasli, M. E., and Seman, I. A. 2013. Composition and Diversity of Plant Seedlings and Saplings at Early Secondary Succession of Fallow Lands in Sabal, 
Sarawak. Acta Biologica Malaysiana 2(3): 85-94. DOI: 10.7593/abm/2.3.85

Kershaw, J. A. J., Ducey, M. J., Beers, T. W., and Husch, B. 2016. Forest Mensuration. WileyBlackwell, New York, USA.

Khalil, H. P. S. A., Hossain, M. S., Rosamah, E., Azli, N. A., Saddon, N., Davoudpoura, Y., Islam, M. N., and Dungani, R. 2015. The Role of Soil Properties and It's Interaction Towards Quality Plant Fiber: A Review. Renewable and Sustainable Energy Reviews Elsevier Ltd. DOI: 10.1016/j.rser.2014.11.099

Laksemi, N. P. S. T., Sulistyawati, E., and . M. 2019. Perhutanan Sosial Berkelanjutan di Provinsi Bali (Studi Kasus di Hutan Desa Wanagiri). Jurnal Sylva Lestari 7(2): 150-163. DOI: $10.23960 /$ js127150-163

Martawijaya, A., Kartasujuna, I., Kadir, K., and Prawira, S. A. 2005. Atlas Kayu Indonesia Jilid I (Edisi Revisi). Badan Penelitian dan Pengembangan Kehutanan Departemen Kehutanan, Bogor, Indonesia. DOI: 10.18196/jgpp.2016.0056

Omayio, D., and Mzungu, E. 2019. Modification of Shannon-Wiener Diversity Index towards Quantitative Estimation of Environmental Wellness and Biodiversity Levels Under a NonComparative Scenario. Journal of Environment and Earth Science 9(9): 46-57. DOI: 10.7176/jees/9-9-06

Pamoengkas, P., Siregar, I. Z., and Dwisutono, A. N. 2018. Stand Structure and Species Composition of Merbau in Logged-Over Forest in Papua, Indonesia. Biodiversitas 19(1): 163-171. DOI: 10.13057/biodiv/d190123

Pamoengkas, P., Zamzam, A., and Dwisutono, A. 2019. Vegetation Recovery of Logged-Over Dipterocarp Forests In Central Kalimantan, Indonesia. Floresta e Ambiente 26(3): 1-11. DOI: $10.1590 / 2179-8087.123917$

Resmeiliana, I., Sofyan, K., and Achmadi, S. S. 2014. Karakteristik Asam Resin Kopal Agathis loranthifolia Sukabumi. Jurnal Sains Terapan 4(2): 13-17.

Rosalia, N. 2008. Penyebaran dan Karakteristik Tempat Tumbuh Pohon Tembesu (Fragraea fragrans Roxb) (Studi Kasus Di Kawasan Taman Nasional Danau Sentarum Kapuas Hulu Kalimantan Barat). Institut Pertanian Bogor.

Saputra, A. D., Indriyanto, and Duryat. 2016. Komposisi, Struktur, Dan Keanekaragaman Jenis Vegetasi Di Jalur Wisata Air Terjun Wiyono Atas Taman Hutan Raya Wan Abdul Rachman Provinsi Lampung. Jurnal Sylva Lestari 4(3): 83-96. DOI: 10.23960/js13483-96 Siahaan, K., Dewi, B. S., and Darmawan, A. 2019. Keanekaragaman Amfibi Ordo Anura di Blok Perlindungan dan Blok Pemanfaatan Hutan Pendidikan Konservasi Terpadu, Taman Hutan Raya Wan Abdul Rachman. Jurnal Sylva Lestari 7(3): 370-378. DOI: 10.23960/js137370-378

Siburian, R. H. S., Siregar, U. J., and Siregar, I. Z. 2017. Genetic Variation of Gyrinops Verstegii Originated From Papua Based on RAPD. Asian Journal of Microbiology, Biotechnology and Environmental Sciences 19(3): 1-5.

Sofiah, S., Metusala, D., Trimanto, and Nurfadilah, S. 2018. Flora Diversity, Composition and Ecology in Besiq Bermai Tropical Forest of Damai District, East Kalimantan. Biotropia 25(2): 85-94. DOI: 10.11598/btb.2018.25.2.724

Tiurmasari, S., Hilmanto, R., and Herwanti, S. 2016. Analisis Vegetasi dan Tingkat Kesejahteraan Masyarakat Pengelola Agroforestri di Desa Sumber Agung Kecamatan Kemiling Kota Bandar Lampung. Jurnal Sylva Lestari 4(3): 71-82. DOI: 10.23960/js13471-82

Trogisch, S., Schuldt, A., Bauhus, J., Blum, J. A., Both, S., Buscot, F., Castro-Izaguirre, N., Chesters, D., Durka, W., Eichenberg, D., Erfmeier, A., Fischer, M., Geißler, C., Germany, M. S., Goebes, P., Gutknecht, J., Hahn, C. Z., Haider, S., Härdtle, W., He, J. S., Hector, A., Hönig, L., Huang, Y., Klein, A. M., Kühn, P., Kunz, M., Leppert, K. N., Li, Y., Liu, X., Niklaus, P. A., Pei, Z., Pietsch, K. A., Prinz, R., Proß, T., Scherer-Lorenzen, M., 
Schmidt, K., Scholten, T., Seitz, S., Song, Z., Staab, M., von Oheimb, G., Weißbecker, C., Welk, E., Wirth, C., Wubet, T., Yang, B., Yang, X., Zhu, C. D., Schmid, B., Ma, K., and Bruelheide, H. 2017. Toward a Methodical Framework for Comprehensively Assessing Forest Multifunctionality. Ecology and Evolution 7(24): 10652-10674. DOI: 10.1002/ece3.3488

Turkis, S., and Elmas, E. 2018. Tree Species Diversity and Importance Value of Different Forest Communities in Yenice Forests. Fresenius Environmental Bulletin 27(6): 4440 4447.

Wahyudi, A., Harianto, S. P., and Darmawan, A. 2014. Keanekaragaman Jenis Pohon di Hutan Pendidikan Konservasi Terpadu Tahura Wan Abdul Rachman. Jurnal Sylva Lestari 2(3): 1-10. DOI: $10.23960 /$ js1321-10

Wasis, B., Winata, B., and Andriani, R. 2018. Growth of Agathis dammara (Lamb. Rich.) Seedling on Gold Tailing with Addition of Coconut Shell Charcoal and Compost. Archives of Agriculture and Environmental Science 3(2): 131-136. DOI: $10.26832 / 24566632.2018 .030205$ 